\title{
TOTAL BAKTERI Escherichia coli PADA AIR PENCUCI IKAN DI TEMPAT PELELANGAN IKAN PASAR BERSEHATI MANADO
}

\author{
Dessy Ateta, Engel V. Pandey, Frans G. Ijong \\ Fakultas Perikanan dan Ilmu Kelautan, Universitas Sam Ratulangi, Manado, Sulawesi Utara.
}

\begin{abstract}
ABSTRAK
Penelitian ini bertujuan untuk mengetahui keberadaan bakteri E. coli pada air pencuci di TPI Pasar Bersehati Kota Manado. Hasil penelitian diharapkan memberikan informasi mengenai keberadaan bakteri E. coli pada air pencuci di TPI Pasar Bersehati Kota Manado. Penelitian ini dilaksanakan di TPI Pasar Bersehati dalam fokus pada air pencuci ikan, sedangkan untuk analisa mikrobiologis bertempat di Laboratorium Mikrobiologi Pengolahan Hasil Perikanan, Fakultas Perikanan dan Ilmu Kelautan Universitas Sam Ratulangi Manado. Pengambilan sampel air dilakukan pada saat kegiatan di TPI Pasar Bersehati sedang berlangsung. Air pencucian diambil dari air laut dan air PAM dengan cara sampel dimasukan dalam botol sebanyak volume botol dan masukan dalam cool box selama transportasi dari TPI ke Laboratorium. Sampling dilakukan sebanyak satu kali dalam ulangan 1 kali. $A_{1}=$ pengambilan pertama sampel air laut, $A_{2}=$ pengambilan kedua sampel air laut, $B_{1}=$ pengambilan pertama sampel air PAM, $B_{2}=$ pengambilan kedua sampel air PAM. Total koliform dalam $100 \mathrm{ml}$ sampel air yaitu: $\mathrm{A}_{2}=150$, $\mathrm{B}_{2}=0$. Jumlah bakteri secara umum, total koliform dan E. coli lebih banyak pada sampel A2.
\end{abstract}

Kata kunci: Eschericia coli, air pencuci ikan, tempat pelelangan ikan.

\section{PENDAHULUAN}

Salah satu penyebab terjadinya kerusakan atau kebusukan pada produk ikan adalah akibat aktivitas bakteri yang ada pada tubuh ikan itu sendiri maupun dari lingkungan tempat hidupnya. Keberadaan bakteri ini dapat menimbulkan penyakit berupa keracunan atau infeksi.

Keracunan dapat terjadi karena tertelannya racun atau toksin yang dihasilkan oleh bakteri yang bersifat toksik sehingga menimbulkan gejala penyakit. Sedangkan infeksi terjadi karena masuknya bakteri atau mikroba lainnya ke dalam tubuh, menembus system pertahanan tubuh dan hidup serta berkembang biak di dalam tubuh kemudian menimbulkan penyakit.

Menurut (Supardi dan Sukamto, 1999) jenis-jenis bakteri yang terdapat pada air pencuci antara lain yaitu Escherichia coli, Flavobacterium, Pseudomonas Staphylococcus. Bakteri-bakteri ini ada yang bersifat patogen dapat menimbulkan penyakit.

Tempat Pelelangan Ikan (TPI) merupakan salah satu tempat yang banyak dikunjungi oleh masyarakat umum. Sanitasi yang tidak memenuhi persyaratan akan menimbulkan masalah kesehatan diantaranya adalah and food borne disease dan munculnya vektor penyakit (Sri Laksmi, B.J., 1988). TPI dalam menjalankan usahanya harus memenuhi persyaratan higienis dan sanitasi. Menurut Keputusan Menteri Kesehatan Republik Indonesia Nomor 1098/Menkes/SK/ VII/VII/2003 tentang persyaratan higienis dan sanitasi TPI yaitu terdiri dari persyaratan lokasi dan bangunan, persyaratan fasilitas sanitasi seperti air bersih, alat-alat yang digunakan, tempat penyimpanan bahan baku persyaratan penyajian makanan dan persyaratan peralatan yang digunakan. Alat-alat yang digunakan dalam proses pelelangan sering terkontaminasi oleh E. Coli yang berasal dari air yang digunakan untuk mencuci. Kontaminasi bakteri ini pada pangan atau alat pengolahan merupakan suatu tanda praktek sanitasi yang kurang baik (Sri Laksmi, B. J., 1988). TPI yang higienis dan sanitasinya kurang baik akan beresiko untuk kesehatan para konsumen yang ada di TPI tersebut karena TPI juga merupakan tempat terjadinya penularan penyakit secara tidak langsung. TPI Pasar Bersehati juga merupakan tempat umum yang memiliki banyak konsumen. Oleh sebab itu peneliti tertarik untuk melakukan penelitian tentang keberadaan $E$. coli pada peralatan di TPI Pasar Bersehati Manado.

E. coli adalah bakteri gram negatif berbentuk batang. Sel E. coli mempunyai 
ukuran panjang 2,6-6-0 $\mu$ dan bersifat non-motil atau motil dengan peritrikus flagella (Fardias, 1983).

Program higienis merupakan program kebersihan personalia, prosedur dan fasilitas yang diperlukan. Jadwal kebersihan meliputi semua bangunan, wilayah, pekerja dan peralatan yang terlibat dalam penanganan ikan. Secara terperinci ditentukan jadwal kapan waktu kebersihan dilaksanakan, prosedur yang harus diikuti, jenis alat dan bahan pembersih (air, detergen,sanitizer dan lain-lain) yang digunakan. Program higienis personalia berstandar tinggi, untuk itu semua fasilitas kebersihan harus disediakan untuk mereka khususnya bagi petugas-petugas kebersihan (IIyas,1983). Pengetahuan ini dapat diambil tindakan dan dikembangkan suatu program untuk mencega terjadinya penyakit yang ditularkan melalui bahan pangan yang tercemar oleh mikroorganisme dalam masyarakat program untuk mencegah terjadinya penyakit yang di tularkan melalui bahan pangan disebut sebagai sanitasi dan higienis bahan pangan (Buckle, 1987).

Escherchia coli merupakan mikroorganisme indikator yang dipakai didalam analisis air untuk menguji adanya pencemaran oleh tinja, tetapi memindah sebarannya tidak selalu melalui air, melainkan diteruskan melalui mulut, akan tetapi E. coli pun dapat ditemukan tersebar di alam sekitar kita. Penyebaran secara pasif dapat terjadi melalui makanan atau minuman.

Didalam uji analisis air, E. coli merupakan mikroorganisme yang dipakai sebagai indikator untuk menguji adanya pencemaran air oleh tinja. Didalam kehidupan kita E. coli mempunyai peranan yang cukup penting yaitu selain penghuni tubuh " didalam usus besar" juga E. colimenghasilkan kolisin yang dapat melindungi saluran pencernaan dari bakteri patogenik. Escherchiacoli akan menjadi pathogen bila pindah dari habitan yang normal kebagian lain dalam inang, misalnya, bila $E$. colididalam usus masuk kedalam saluran kandung kemih kelamin dapat menyebabkan sistitis, yaitu suatu peradangan pada selaput lendir organ tersebut.

E. coli umumnya merupakan flora normal saluran pencernaan manusia dan hewan.Memiliki peranan penting dalam system pencernaan manusia karena dapat mensintesa vitamin khususnya vitamin $\mathrm{K}$ tetapi dapat beruba menjadi oportunis pathogen bila hidup di luar usus, misalnya pada infeksi saluran kemih, infeksi luka dan meltitis. Serotype dari E. coli yang dapat menyebabkan diare pada manusia disebut E. coli enteropatogenik (EPEK).

Bakteri ini termasuk basil koliform, hidup aerob fakultatif, membantu mengurangi jumlah oksigen dalam usus sehingga akan tercipta akan suasana anaerobik di usus. Merupakan bakteri gram negatif, umumnya mempunyai fibria dan bersifat motil. Bakteri ini mampu memfermentasikan laktosa dengan cepat sehingga pada media EMB akan membentuk koloni berwarna hijau metalik.

E. coli tumbuh pada kisaran suhu 10 $40^{\circ} \mathrm{C}$ dengan suhu optimum $37^{\circ} \mathrm{C}$, Nilai $\mathrm{AW}$ minimum untuk pertumbuhan $E$. coli adalah kemampuan untuk melakukan adesi pada sel-sel hewan dan manusia. Keberadaan E. coli merupakan indikator adanya pencemaran populasi.

Penelitian ini bertujuan untuk mengetahui keberadaan bakteri E. coli pada air pencuci di TPI Pasar Bersehati Kota Manado. Hasil penelitian diharapkan memberikan informasi mengenai keberadaan bakteri E. coli pada air pencuci di TPI Pasar Bersehati Kota Manado.

\section{METODOLOGI PENELITIAN}

Penelitian ini dilakukan dengan menggunakan metode deskriptif, dengan teknik pengumpulan data menggunakan sampling dilanjutkan dengan uji mikrobiologis. Menurut(Manus O.A dan E. Mantjoro, 1987) bahwa penelitian deskriptif yaitu penelitian yang menuturkan, menganalisa dan mengklarifikasi serta menginterpretasikan data tersebut kemudian membandingkan persamaan dan perbedaan fenomena lalu, mengambil bentuk studi komperatif.

\section{Tata Laksana Penelitian \\ Pengambilan Sampel Air}

Pengambilan sampel air dilakukan pada saat kegiatan di TPI Pasar Bersehati sedang berlangsung. Air pencucian diambil dari air laut dan air PAM dengan cara sampel dimasukan dalam botol sebanyak volume botol dan langsung ditutup masukan dalam cool box selama transportasi dari TPI ke Laboratorium. Sampling dilakukan sebanyak satu kali dalam ulangan 1 kali. 
$\mathrm{A}_{1}=$ Pengambilan pertama sampel air laut.

$\mathrm{A}_{2}=$ Pengambilan kedua sampel air laut.

$\mathrm{B}_{1}=$ Pengambilan pertama sampel air PAM.

$\mathrm{B}_{2}=$ Pengambilan kedua sampel air PAM.

\section{Analisa Coliform dan E. coli}

\section{Uji pendugaan}

1. Siapkan 3 grup tabung reaksi lengkap dengan tabung durham, masing-masing grup terdiri dari 3 seri tabung.

2. Masukan sejumlah $6 \mathrm{ml} \mathrm{Kaldu} \mathrm{Laktosa} \mathrm{ke}$ dalam setiap tabung dan sterilisasi pada suhu $121^{\circ} \mathrm{C}$, pada tekanan 15 psi, selama 15 menit.

3. Sampel dibuat suspense dengan tingkat pengenceran bertingkat $\left(10^{-1}, 10^{-2}\right.$ dan $\left.10^{-3}\right)$ dengan menggunakan larutan $\mathrm{NaCl} 0,9 \%$ steril.

4. Secara aseptik, masukan masing-masing sejumlah $1 \mathrm{ml}$ suspense dari setiap tingkat pengenceran ke dalam setiap seri tabung. Kocok perlahan agar suspense tercampur dengan media dan apabila ada udara dalam tabung durham harus dibebaskan untuk menghindari kesalahan pembacaan hasil.

5. Masukan semua tabung ke dalam inkubator dan inkubasi pada suhu $37^{\circ} \mathrm{C}$ selama 24 jam dan dapat dilanjutkan hingga 48 jam.

6. Catat tabung yang menunjukkan hasil positif, ditunjukkan dengan adanya asam dan gas dalam tabung durham. Bandingkan hasil yang diperoleh dengan tabel Hopkins, dan dinyatakan sebagai Total Coliform (MPN/100 $\mathrm{ml}$ atau gram sampel).

\section{Uji penguatan}

1. Media EMB-Agar sejumlah tabung yang positif (biasanya 1 cawan petri dapat dibagi 3 bagian untuk 3 tabung positif).

2. Secara aseptik, ambil 1 mata ose biakan pada tabung yang positif dan gores pada EMB Agar.

3. Masukan ke dalam inkubator dan inkubasi pada suhu $37^{\circ} \mathrm{C}$ selama semalam.

4. Catat hasil positif yang ditunjukkan dengan tumbuhnya tipikal koloni E. coli. Bandingkan hasil yang diperoleh dengan tabel Hopkins, dan dinyatakan sebagai Total E. coli (MPN/100 ml atau gram sampel).

\section{Uji lengkap}

1. Siapkan media kaldu laktosa dan dengan menggunakan jarum ose pindahkan tipikal koloni bebas ke dalam media tersebut.
2. Inkubasi pada suhu $37^{\circ} \mathrm{C}$ selama semalam dan amati adanya pembentuk asam dan gas.

3. Secara aseptik ambil 1 mata ose dan goreskan pada media NA, selanjutnya inkubasi pada suhu $37^{\circ} \mathrm{C}$ selama semalam.

4. Uji koloni yang tumbuh pada NA terhadap gram-pewarnaan. Uji akan melengkapi kesimpulan uji penguatan apabila hasil yang diperoleh sebagai berikut: terbentuknya asam dan gas pada Kaldu Laktosa serta sel bakteri memiliki sifat gram-negatif dan bentuk batang.

\section{HASIL DAN PEMBAHASAN}

\section{Analisa Total Koliform dan E. coli}

Pengujian koliform menggunakan media EC mediun. Dalam media EC Medium menunjukkan bahwa tabung positif adalah bakteri koliform yang menghasilkan asam dan gas dalam tabung durham. Hasil pengamatan pada media EC medium menunjukkan pertumbuhan $E$. coli paling banyak terdapat pada sampel air laut yaitu pengambilan kedua adalah $\mathrm{A}_{2}=150$. Nilai rata-rata Total Coliform dan E. coli dapat dilihat pada Tabel 2. Sedangkan hasil uji positif koliform dapat dilihat pada Gambar 1.

Tabel 01. Nilai rata-rata total koliform dan $E$. coli pada air pencuci ikan.

\begin{tabular}{ccc}
\hline Sampel Air & $\begin{array}{c}\text { Koliform } \\
\text { (MPN/100 ml ) }\end{array}$ & $\begin{array}{c}\text { Total E. coli } \\
\text { ( MPN/ 100 ) }\end{array}$ \\
\hline $\mathrm{A}_{1}$ & 0 & 0 \\
$\mathrm{~A}_{2}$ & 150 & 4 \\
$\mathrm{~B}_{1}$ & 0 & - \\
$\mathrm{B}_{2}$ & 0 & - \\
\hline
\end{tabular}

Keterangan: $\mathrm{A}_{1}$ (air laut pengambilan pertama); $\mathrm{A}_{2}$ (air laut pengambilan kedua); $\mathrm{B}_{1}$ (air PAM pengambilan pertama); $\mathrm{B}_{2}$ (air PAM pengambilan kedua).

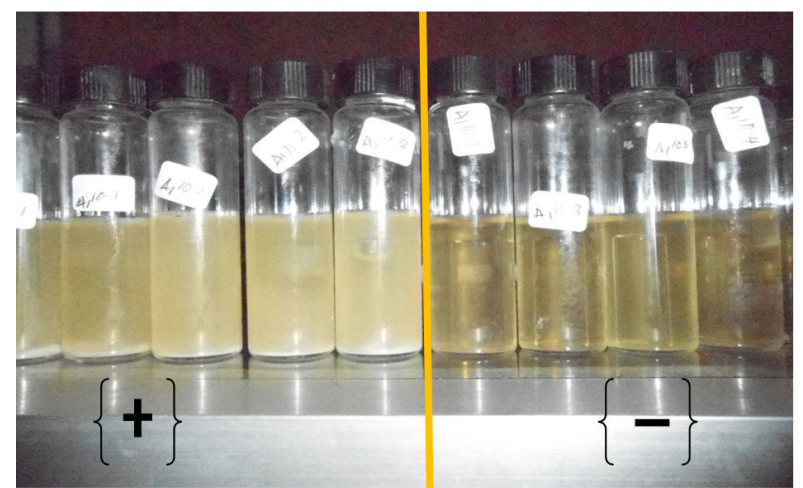

Gambar 1. Hasil uji koliform

Total koliform terbanyak pada sampel $\mathrm{A}_{2}$ yaitu 150 dan juga total $E$. coli tertinggi pada sampel $\mathrm{A}_{2}$ yaitu 4. Total koliform dan $E$. coli terendah pada sampel $A_{1}, B_{1}, B_{2}$ yaitu 0 . 
Adanya E. coli dari air pencucian ikan dikarenakan ikan tersebut sudah terkontaminasi atau air pencucian tidak memenuhi standar atau syarat sebagai air pencucian.

Pada Gambar 1 menunjukkan bahwa tabung positif berada pada kiri gambar sedangkan tabung yang negative berada di sebelah kanan.

Kontaminasi kemungkinan berasal dari air laut yang digunakan, pedagang yang tidak memperhatikan kesehatan dan kebersihan pribadi, alat yang digunakan, ikan sebagai bahan jualan, wadah pencuci, saluran air atau lingkungan TPI pencucian. Oleh sebab itu, perlu pengendalian terhadap faktor-faktor kontaminasi di atas dengan cara meningkatkan pengawasan mutu, terutama sanitasi dan higienis selama pencucian ikan.

Tingginya koliform dan E. coli pada sampel $\mathrm{A}_{2}$ kemungkinan berasal dari bahan baku ikan yang digunakan dalam pencucian peralatan pekerja yang tidak memperhatikan sanitasi selama pekerjaan. Sampel $A_{1}$ tidak ditemukan koliform dan $E$. coli kecuali sampel $\mathrm{A}_{2}$ koliform pada sampel $\mathrm{A}_{2}=150$ dan $E$. coli $=$ 40. Adanya bakteri tersebut kemungkinan kontaminasi dari sumber air PAM. Dan juga sekitar pasar TPI yang kurang bersih sehingga fluktuasi jumlah koliform dan E. coli yang ditemukan dipengaruhi oleh lingkungan sekitar sumber air PAM dan laut tersebut.

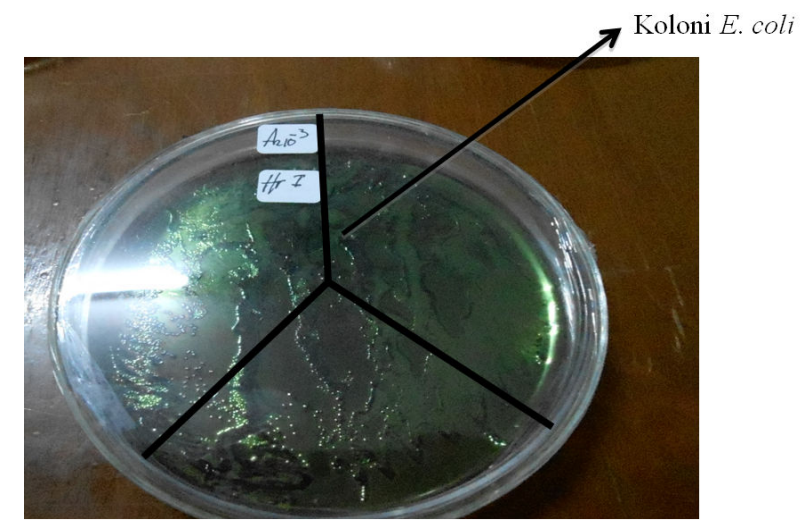

Gambar 2. Penampakan koloni E. coli pada EMB Agar.

\section{KESIMPULAN}

Kontaminasi kemungkinan berasal dari air laut yang digunakan, pedagang yang tidak memperhatikan kesehatan dan kebersihan pribadi, alat yang digunakan, ikan sebagai bahan jualan, wadah pencuci, saluran air atau lingkungan TPI pencucian. Oleh sebab itu, perlu pengendalian terhadap faktor-faktor kontaminasi di atas dengan cara meningkatkan pengawasan mutu, terutama sanitasi dan higienis selama pencucian ikan.

Total koliform dalam $100 \mathrm{ml}$ sampel air yaitu: $A_{2}=150, B_{2}=0$. Jumlah bakteri secara umum, total koliform dan E. coli lebih banyak ditentukan pada sampel $\mathrm{A}_{2}$. Koloni yang tumbuh pada media EMB Agar berupa E. coli adalah berwarna hijau metalik.

\section{DAFTAR PUSTAKA}

Anonimous. 1993. Mikrobiologi Kedokteran, Edisi Revisi. Binarupa Aksara. Jakarta Barat.

Buckle, K.A. Edwards, R. A. Fleet, G. H, Wooton, M. 1987. Ilmu Pangan. Penerjemah: Hari Adiono. Penerbit Universitas Indonesia. Jakarta

Capuccino dan Sherman (1992). Microbiology A Laboratory Manual. Third Edition. Benjamin Cummings Science Publishing. California.

Dundu, B., 2000. Penuntun Praktikum Mikrobiologi. Fakultas Pertanian. UNSRAT Manado.

Fardiaz, S., 1983. Keamanan Pangan. Jurusan Ilmu dan Teknologi Pangan. Fakultas Teknologi Pertanian. Institut Pertanian Bogor.

IIyas, S. 1983. Teknologi Refrigerasi Hasil Perikanan Jilid 1. Teknik pendinginan Ikan CV. Paripurna. Jakarta.

Irawan, H.S.R., 1995. Pengolahan Hasil Perikanan. Penerbit Agency. Solo.

Junianto, 2003. Teknologi Penanganan Ikan. Swadaya. Jakarta.

Lay, B.W., 1994. Analisis Mikroba di Laboratorium. PT. Raja Grafindo Persada. Jakarta.

Manus O.A dan E. Mantjoro, 1987. Metodologi Penelitian. Fakultas Perikanan. UNSRAT. MANADO.

Purnomo, H., 1995. Aktivitas Air dan Peranannya dalam Pengawetan Bahan Pangan. Universitas Indonesia Press.

1987.Standar Nasional Indonesia (SNI), Air Minum, Syarat dan Pengawasan Jakarta. Supardi dan Sukamto, 1999.Mikrobiologi dalam Pengolahan dan Keamanan Pangan. Jurusan Ilmu dan Teknologi Pangan. Fakultas Teknologi Pertanian. IPB Bogor.

Sri Laksmi, B. J. 1988. Sanitasi Dalam Industri Pangan. Penerbit Kanisius Kerja sama Dengan Pusat Antar Universitas Pangan Dan Gizi, IPB. Bogor 